\title{
Pelatihan Mindfulness dalam Rangka Menghadapi Ujian Nasional pada Siswa Kelas XII SMKN 14 Jakarta
}

\author{
Dewi Kumalasari, Endang Fourianalistyawati, Arif Triman, Johan Satria Putra \\ Fakultas Psikologi, Universitas Yarsi \\ dewi.kumalasari@yarsi.ac.id
}

\begin{abstract}
ABSTRAK
Ujian Nasional merupakan sebuah momen yang memberikan beban yang berat pada siswa di Indonesia. Hal ini menimbulkan emosi-emosi negatif pada diri siswa yang dapat berdampak buruk pada performa siswa dalam menghadapi ujian, terutama dalam kemampuan untuk memusatkan perhatian/daya konsentrasi, baik dalam persiapan maupun dalam pelaksanaan ujian. Oleh karena itu, perlu adanya pendekatan khusus bagi siswa yang akan menghadapi ujian untuk membantu mereka dalam memusatkan perhatian. Mindfulness didefinisikan sebagai kemampuan untuk memberi atensi atau perhatian terhadap diri secara apa adanya tanpa memberikan penilaian serta menerima segala pengalaman yang muncul saat ini. Pelatihan menggunakan teknik mindfulness ini diharapkan dapat membantu siswa lebih percaya diri dan memiliki daya konsentrasi yang lebih baik. Program ini akan dilakukan dalam bentuk pelatihan secara intensif selama satu hari, berisi materi tentang mindfulness, dengan menyertakan latihan teknik-teknik sederhana dalam mindfulness. Pelatihan diberikan pada siswa kelas XII SMKN 14 dari ketiga jurusan yang ada di sekolah tersebut. Hasil evaluasi menunjukkan adanya peningkatan kondisi mindfulness dan daya konsentrasi pada siswa yang terlihat dari kuesioner mindfulness yang diisi saat pre-test, post-test dan follow up.
\end{abstract}

Kata Kunci: Pelatihan Mindfulness, Kesadaran Diri, Daya Konsentrasi, Ujian Nasional, Siswa.

\begin{abstract}
National Exam/ Ujian Nasional (UN) is the moment that puts a heavy load for students in Indonesia. It brings out negative emotions on student that could affect student's performance in exam, especially in the ability to concentrate, both in preparation and in execution of the exam. Therefore, it needs a special approach for students who will face the exam to help them concentrate/focus. Mindfulness is defined as the ability to give attention or attention to the self without judgement and accept all current and emerging experience. Training using mindfulness techniques are expected to help students more confident and more focused. This program will be conducted in the form of intensive training for one day, contains material about mindfulness, the practice includes simple techniques in mindfulness. The training given to the students of class XII SMK 14 of the three departments in the school. The evaluation results showed an increase mindfulness conditions and the ability to focus on students as seen from the mindfulness questionnaires filled as a pre-test, post-test and follow-up.
\end{abstract}

Keywords: Mindfulness Training, Self-Awareness, Focus, National Exam 


\section{PENDAHULUAN}

Ujian merupakan salah satu tahapan yang harus dilalui oleh setiap siswa untuk menyelesaikan pendidikan sekolah dasar, sekolah menengah pertama maupun sekolah menengah atas. Ujian digunakan sebagai acuan untuk melihat bagaimana pemahaman siswa terhadap proses belajar mengajar yang dilakukan di sekolah. Oleh karena itu, ujian itu sendiri tentunya memberikan sebuah beban tersendiri bagi siswa. Penelitian yang dilakukan oleh Lotz \& Sparfeltz (2016) menemukan bahwa beban pendidikan yang tinggi memiliki keterkaitan dengan rasa cemas yang dirasakan oleh siswa. Terlebih situasi yang dihadapi menjelang ujian, biasanya bisa mendatangkan tekanan dan beban pikiran yang begitu besar bagi siswa (Bamber \& Schneider, 2016).

Di Indonesia sendiri, salah satu ujian yang sangat menjadi beban bagi siswa adalah Ujian Nasional. Hal ini dikarenakan Ujian Nasional menjadi acuan bagi setiap siswa untuk melanjutkan pendidikannya ke jenjang yang lebih tinggi. Ujian Nasional sendiri diselenggarakan pada setiap jenjang pendidikan, seperti sekolah dasar, sekolah menengah pertama maupun pada tingkat sekolah menengah atas. Pada tahun 2012, Kementrian Pendidikan dan Kebudayaan melakukan survey terkait dengan kecemasan yang dihadapi siswa SMA dalam menghadapi Ujian Nasional. Hasil dari survey ini mendapati $56 \%$ siswa SMA yang akan menghadapi ujian mengalami kecemasan. Ditambah lagi dengan situasi sebelum Ujian Nasional yang seharusnya dimanfaatkan untuk menenangkan diri oleh para siswa, diisi dengan kegiatan- kegiatan yang memicu kecemasan mereka semakin meningkat. Seperti kelas tambahan, beban belajar yang ditambah serta kegiatan lainnya. Hal ini tentunya dapat mempengaruhi kondisi psikologis terutama rasa cemas yang dirasakan oleh siswa tersebut. 
Kecemasan menjelang Ujian Nasional merupakan salah satu emosi negatif yang dapat menimbulkan dampak stres secara psikologis dan menimbulkan berbagai masalah fisik pada siswa. Lebih jauh, emosi negatif yang dialami dapat membuat kemampuan siswa dalam memusatkan perhatian menjadi terganggu. Oleh karena itu, siswa yang sedang mempersiapkan diri untuk ujian memerlukan pendekatan khusus dalam membantu menjadi lebih fokus, menyadari pengalaman dan kondisi yang sedang dialami, mengurangi emosi negatif dalam menghadapi perkembangan diri, agar tidak mempengaruhi kemampuan dan fokus dalam belajar. Pelatihan mindfulness merupakan salah satu pelatihan yang ditawarkan untuk membantu meningkatkan kesadaran dan kemampuan memusatkan perhatian pada siswa yang akan menghadapi ujian.

Melalui pelatihan mindfulness yang diberikan pada siswa yang akan menghadapi ujian nasional ini, dengan proses pelatihan yang lebih fokus pada experiential learning, dapat meningkatkan kesadaran, konsentrasi, dan kepercayaan diri dalam menghadapi ujian. Peningkatan kesadaran ini juga diharapkan membantu meminimalisir gejolak emosi yang tidak stabil pada masa-masa menjelang ujian sehingga dapat mempersiapkan diri dengan optimal.

Sasaran kegiatan ini adalah siswa kelas XII SMKN 14 yang akan memasuki tahap ujian akhir.

\section{METODE}

Program ini akan dilakukan dalam bentuk pelatihan, yang dilakukan selama satu hari. Pelatihan diawali dengan sesi pre-test, dilanjutkan pengenalan konsep mindfulness serta diperkuat dengan latihan teknik mindfulness melalui kegiatan menggambar, body 
awareness dan pernafasan. Kegiatan pelatihan ditutup dengan post-test. Selanjutnya, peserta diminta untuk mempraktikkan secara mandiri teknik yang sudah dipelajari selama satu minggu. Praktik mandiri akan dimonitoring pelaksanaannya menggunakan lembar self monitoring, dan dilakukan follow up, satu minggu setelah pelaksanaan pelatihan.

Untuk mengetahui sejauh mana tujuan telah tercapai, maka dilakukan pre test dan post test. Adapun instrument yang digunakan adalah sebagai berikut:

1. Cognitive Affective Mindfulness Scale (CAMS) yang akan mengukur tingkat pemahaman dan kesadaran dari para peserta. Skala ini berisi 10 aitem pernyataan yang merefleksikan kesadaran diri para peserta.

2. Tugas 'Jenius Reading' untuk mengukur kemampuan siswa dalam memusatkan perhatian. Dalam tugas ini, peserta diberikan 25 soal mencocokkan kata. Peserta diminta untuk mengerjakan secepat dan seteliti mungkin. Tugas ini merefleksikan kemampuan peserta dalam memusatkan perhatian pada pengerjaan tugas.

\section{Teknik Pengolahan Data}

Dalam penelitian ini, teknik pengolahan data yang dilakukan adalah dengan membandingan rerata skor pre-test, post-test dan follow up pada dua skala yang digunakan. Pelatihan dikatakan berhasil apabila terdapat peningkatan skor sebelum dan setelah follow up.

\section{HASIL DAN PEMBAHASAN}

Dalam program ini, dilakukan 2 jenis evaluasi, yaitu evaluasi kesadaran diri serta evaluasi kemampuan memusatkan perhatian. Berikut penjelasan setiap jenis evaluasi

\section{$\underline{\text { Kesadaran Diri }}$}


Evaluasi kesadaran diri diukur melalui instrument Cognitive Affective Mindfulness Scale (CAMS) yang diberikan pada saat pre-test, post-test dan follow up. Tujuan dianggap tercapai apabila terjadi peningkatan skor CAMS dibandingkan sebelumnya. Pada saat follow up juga akan diberikan kembali lembar CAMS untuk mengetahui sejauh mana kesadaran diri peserta setelah mempraktikkan teknik mindfulness dalam satu pekan. Berikut adalah skor CAMS dari waktu ke waktu:

\section{Gambar 1. Perubahan Skor CAMS dari waktu ke waktu}

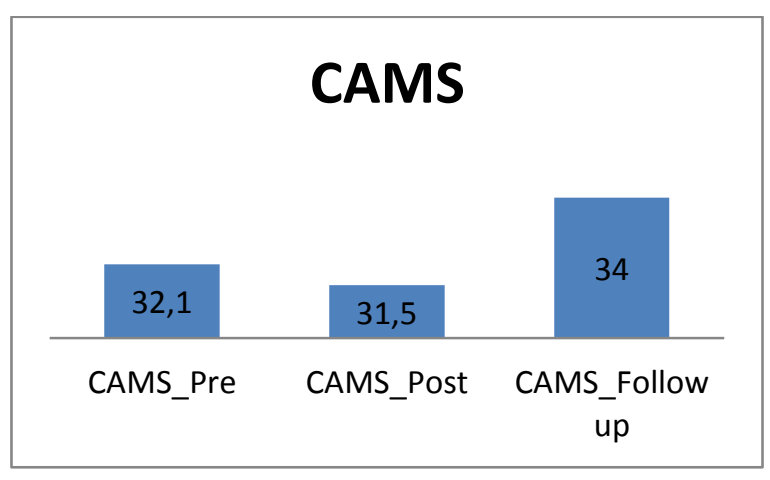

Berdasarkan data, terlihat bahwa pelatihan mindfulness terbukti meningkatkan kesadaran diri peserta apabila peserta mempraktikkannya secara rutin. Hal ini tampak dari adanya peningkatan skor yang cukup tinggi dari pre-test dan follow up. Hasil ini mengindikasikan bahwa sesuai dengan penelitian sebelumnya bahwa pelatihan meditasi mindfulness akan bisa bermanfaat bagi adanya peningkatan kesadaran diri individu akan situasi di sini dan saat ini serta menurunkan kecemasan.

\section{Kemampuan Memusatkan Perhatian}

Evaluasi kemampuan memusatkan perhatian diukur melalui tugas 'Jenius Reading' . Tujuan dianggap tercapai apabila terjadi peningkatan skor Jenius Reading dibandingkan sebelumnya. Pada saat follow up juga akan diberikan kembali lembar Jenius Reading untuk mengetahui sejauh 
mana kemampuan peserta dalam memusatkan perhatian setelah mempraktikkan teknik mindfulness dalam satu pekan. Berikut adalah peningkatan skor Jenius Reading:

\section{Gambar 2. Perubahan Skor 'Jenius Reading' dari waktu ke waktu}

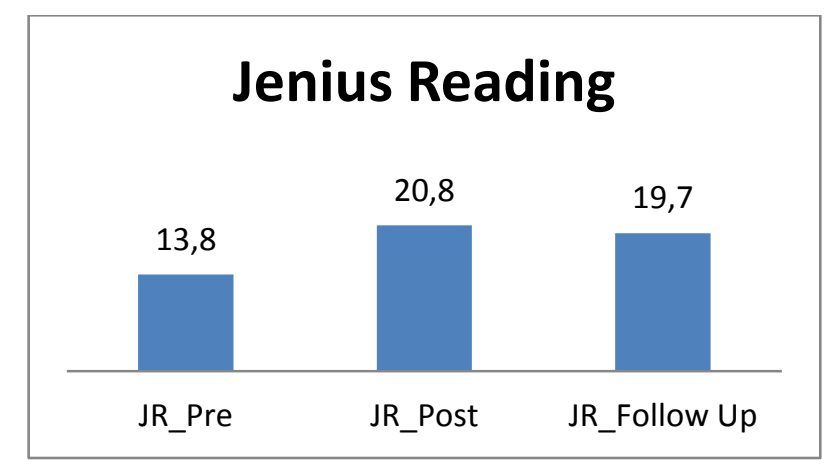

Berdasarkan data, terlihat bahwa pelatihan mindfulness terbukti meningkatkan kemampuan peserta dalam memusatkan perhatian. Hal ini tampak dari adanya peningkatan skor yang cukup tinggi dari pre-test dan post-test. Hasil ini mengindikasikan bahwa pelatihan mindfulness dapat meningkatkan fungsi kognitif, khususnya dalam kemampuan memusatkan perhatian, sejalan dengan penelitian Chiesa, Calati dan Serreti (2011).

\section{KESIMPULAN DAN SARAN}

\section{Kesimpulan}

Merujuk pada indikator kinerja serta evaluasi program, terlihat bahwa program pelatihan mindfulness yang diberikan, dapat dikatakan efektif untuk meningkatkan kondisi kesadaran serta kemampuan siswa dalam memusatkan perhatian. Diharapkan dengan adanya hasil dari pelatihan ini, siswa yang merasakan manfaatnya akan mampu memiliki kesehatan mental, atensi dan fokus yang baik dalam menghadapai tantangan dalam kehidupan akademiknya. 


\section{Saran}

Berdasarkan evaluasi pelaksanaan kegiatan, terdapat hal-hal yang perlu diperhatikan apabila program ini akan dilakukan kembali, yaitu:

1. Waktu pelaksanaan hendaknya diatur tidak terlalu mepet dengan jadwal UN sehingga peserta memiliki waktu yang lebih panjang untuk mempraktikkan teknik yang diajarkan dalam pelatihan sehingga dapat mempersiapkan UN dengan lebih baik lagi.

2. Terkait dengan efektivitas jangka panjang, maka program pelatihan mindfulness sebaiknya dilakukan secara lebih intensif dan dalam jangka waktu yang berkesinambungan. Penelitian terdahulu menunjukkan bahwa diperlukan waktu 8 sesi untuk mampu benar-benar mencapai hasil yang optimal.

\section{DAFTAR PUSTAKA}

Badudu, Ananda. (2012, 20 April). 56 Persen Siswa SMA Cemas Hadapi Ujian Nasional. Tempo. Diakses pada tanggal 26 Oktober 2016 dari https://nasional.tempo.co/read/news/2012/04/20/079398556/56-persen-siswa-sma-cemashadapi-ujian-nasional

Bamber, M. D., \& Schneider, J. K. (2016). Mindfulness-based meditation to decrease stress and anxiety in college students: A narrative synthesis of the research. Educational Research Review: 18, 1-32.

Chiesa, A., Calati, R \& Serretti, A. (2011). Does mindfulness training improve cognitive abilities? A systematic review of neuropsychological findings. Clinical Psychology Review: $31,449-464$. 
Dundas, I., et al. (2016). Mindfulness Based Stress Reduction for Academic Evaluation Anxiety: A Naturalistic Longitudinal Study. Journal of College Student Psychotherapy, 30 (2): $114-131$.

Germer, C. K. (2009). The Mindful Path to Self-Compassion. New York: The Guilford Press. Mace, C. (2008). Mindfulness and Mental Health: Therapy, Theory and Science (1st ed.).London and New York: Routledge.

Lotz, C., \& Sparfeldt, J. R. (2017). Does test anxiety increase as the exam draws near? Students' state test anxiety recorded over the course of one semester. Personality and Individual Differences. 104: 397-400. 